\title{
Chemical composition of essential oils from Bambusa vulgaris Leaf (Fresh and Dried) Schrad. Ex J.C. Wendl. [Poaceae] obtained in Nigeria
}

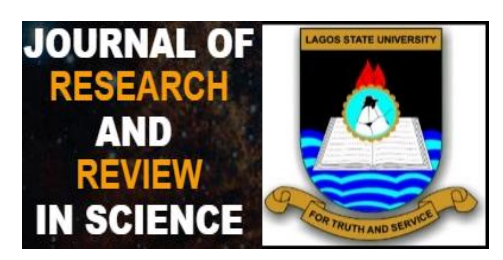

\author{
Odunayo C., Atewolara-Odule $1^{1}$, Oseyemi O., Olubomehin 2 ${ }^{1}$, Enitan A., Adesanya $3^{2}$, Adejumoke M., Hashimi \\ $4^{1}$, Abdulrazaq O., Ogunmoye $5^{1}$
}

${ }^{1}$ Department of Chemical Sciences, Faculty of Science, Olabisi Onabanjo University, P.M.B. 2002, Ago-Iwoye, Ogun State, Nigeria

${ }^{2}$ Department of Pharmacognosy Faculty of Pharmacy, University of Ibadan, Ibadan, Oyo State, Nigeria

\section{Correspondence}

Odunayo Christy Atewolara-Odule, Department of Chemical Sciences, Faculty of Science, Olabisi Onabanjo University, P.M.B. 2002, Ago-Iwoye, Ogun State, Nigeria

Email:atewolara-odule.odunavo@oouago iwoye.edu.ng or odunoc@gmail.com

\section{Funding information}

Not applicable

\begin{abstract}
:
Introduction: Essential oil is a hydrophobic concentrated liquid which contains volatile aroma compounds from plants. Bambusa vulgaris grows widely in the tropical and subtropical regions and has been reported to have different ethnomedicinal values such as antimalaria and antioxidant. It is also known to be an ornamental plant.

Aims: To extract and characterized the essential oils of Bambusa vulgaris.

Materials and Methods: The essential oil was extracted from both the fresh and dried leaves of Bambusa vulgaris by hydro distillation method using a Clevenger apparatus. The chemical constituents of the essential oils were characterized using gas chromatography and gas chromatography-mass spectrometry.

Results: The essential oils obtained were colourless with an herbal odour giving a yield of $0.64 \mathrm{w} / \mathrm{w}$ for the fresh sample and $1.08 \mathrm{w} / \mathrm{w}$ for the dried sample. A total of thirty-nine (39) compounds were identified from the essential oils of both samples. The major constituents in the fresh leaves were 3 -aminodibenzofuran (19.2\%), $\beta$-ocimene (11.1\%), undecane $(9.6 \%)$, tridecane $(8.6 \%),[3,2-b]$ pyridin-6-octahydropyrano $(7.1 \%)$, 2-mono laurin $(6.9 \%)$ and vinyl decanoate (5.9\%). Prominent compounds of the essential oil in the dried leaves were chlorophenoxymethylenimino sulfur pentafluoride $(74.5 \%)$ and 2,2,6,6tetramethyl-3,5-heptanedione (17.3\%). Undecane, tridecane, hexadecane and octadecane were found both in the fresh and dried leaves.

Conclusion: The chemical constituents of the essential oils from Nigeria Bambusa vulgaris were reported in this study for the first time to the best our knowledge and this could be useful in aromatherapy.

To Keywords: Bambusa vulgaris, Clevenger apparatus, essential oils, gas chromatography-mass spectrometry [GC-MS]
\end{abstract}




\section{INTRODUCTION}

Bambusa vulgaris Schrad. Ex J.C. Wendl., commonly known as bamboo in English and 'Oparun' in Yoruba Southwest Nigeria, belongs to the Poaceae family. It grows widely in tropical and subtropical regions throughout the world [1]. It has lemon-yellow culms (stems) with green stripes and dark green leaves. The culms are basically straight or flexuous (bent alternatively in different directions) drooping at the tip [2]. Among the species in the genus, Bambusa vulgaris is one of the largest and most easily recognized and it has been recorded that 75 genera and 1250 species occur in the world [2]. The phytochemical screening of Bambusa vulgaris showed the presence of alkaloids, terpenoids, flavonoids, saponin, tannins, Phytates and Oxalates while the mineral content revealed the presence of calcium, and iron [3]. The main constituents of the culms are holocellulose, pentosans, hemicellulose, lignin and minor constituents like resins, tannins, waxes and inorganic salts [4]. Bambusa vulgaris also contains glucose, fructose and sucrose [5]. B. vulgaris had been reported to contain low fat but high proportion of carbohydrates, dietary fibers, potassium and vitamins. $B$. vulgaris shoots could be consumed raw, fermented, boiled, canned and frozen [6]. It has been reported also to have antidiabetic [7], anti-inflammatory [8], antimicrobial [9] and antifatigue [10] properties. In Nigeria, the decoction of this plant is used for treating diseases like gonorrhea, diarrhea, inflammation, wounds, fever, worm and ulcer $[11,12,13]$. The processes of wound healing and the orderly scheme are disturbed as a result of bacteria and bacteria products like endotoxins and metalloproteinase [14]. Science and communities have benefited from some genius of $B$. vulgaris [15]. Despite all these ethno pharmacological properties little is known about the essential oil constituents of Bambusa vulgaris, hence this study aims at isolating its essential oil and characterizing its composition.

\section{MATERIALS AND METHODS / EXPERIMENTAL DETAILS / METHODOLOGY}

\subsection{Plant materials}

Fresh leaves $(1 \mathrm{~kg}$ ) of Bambusa Vulgaris (Poaceae) were collected from Olabisi Onabanjo University, AgoIwoye. The plant was identified at the Department of Plant Science and Applied Zoology of Olabisi Onabanjo University and then authenticated from Forestry Research Institute of Nigeria (FRIN), Ibadan where a voucher specimen was deposited with the Herbarium Number FHI 111967.

\subsection{Isolation of Essential Oils}

The fresh $(500 \mathrm{~g})$ and dried (185 g) leaves were hydrodistilled in an all glass Clevenger-type apparatus for four hours $(4 \mathrm{~h})$ in each case. The oils obtained were dried over anhydrous sodium sulphate $\left(\mathrm{Na}_{2} \mathrm{SO}_{4}\right)$, stored in vials and kept inside a refrigerator until ready for analysis.

\subsection{Gas chromatography (GC)}

The essential oils were subjected to $G C$ analysis on an Agilent model 7890A. A gas chromatograph fitted with a flame ionization detector (FID) and DB-5 (30 x 1.0 $\mathrm{mm}, 0.25 \mu \mathrm{m}$ film thickness). Helium was used as carrier gas at $99.99 \%$ purity on a stationary phase column (HP5 MS). The GC oven temperature was programmed at $75^{\circ} \mathrm{C}$ (held for $3 \mathrm{~min}$ ) at $4^{\circ} \mathrm{C} / \mathrm{min}$ heated to $250^{\circ} \mathrm{C}$ (held for $10 \mathrm{~min}$ ), with final hold time of $58.14 \mathrm{~min}$. Injector and detector temperatures were fixed at $75^{\circ} \mathrm{C}$ and $250^{\circ} \mathrm{C}$ respectively.

\subsection{Gas chromatography-mass spectrometry (GC-MS)}

The GC-MS analyses were performed on an Agilent model 5975C GC-MSD system with split/splitless automated injection interfaced to a 5973 mass selective detector operated at $70 \mathrm{eV}$ with a mass range of $\mathrm{m} / \mathrm{z} 50-500$. The oven temperature was programmed from $70-280^{\circ} \mathrm{C}$ (held for $5 \mathrm{~min}$ ) at a rate of $4{ }^{\circ} \mathrm{C} / \mathrm{min}$. The same operations and temperature programming were used as for GC. Relative percentage amounts of the separated compounds were calculated from FID chromatograms.

\subsection{Identification of components}

Identification of the essential oil components were based on their retention indices (determined with a reference to a homologous series of n-alkanes) and by comparison of their mass spectral fragmentation patterns in computer matching against in-built data (NIST database/Chemstation data system) with data previously reported in the literature $[16,17]$ and the use of pherobase (www.pherobase.net).

\section{RESULTS AND DISCUSSION}

The essential oils of Bambusa vulgaris of both the fresh and dried leaves were found to be colourless with an herbal smell. The yield obtained from the hydrodistillation of both the fresh and dried leaves were $0.64 \%$ and $1.08 \%$ respectively which is similar to the percentage yield of essential oils from Bambusa vulgaris from China [18].Gas chromatography-mass spectrometry (GC-MS) analysis of the essential oil of fresh Bambusa vulgaris leaves revealed the presence of twenty-five constituents representing $96.9 \%$ of the total oils whereas in the dried leaves, there were nineteen components making up $99.9 \%$ of the total oil as shown in Table I. The major compounds found in the fresh leaves essential oil are 3-aminodibenzofuran (19.2\%), Ocimene (11.1\%), Undecane (9.6\%), Tridecane (8.6\%), [3,2-b]pyridin-6-on octahydropyrano (7.1\%), 2-mono Laurin (6.9\%), $\beta$ - Vinyl decanoate $(5.9 \%)$, while the minor constituents are Decanoyl 
chloride (4.8\%), Lauric anhydride (4.1\%), 1-mono laurin (4.1\%), Dodecane (3.3\%), Dodecanoic acid, ethenyl ester (3.1\%) and Nerolidol (3.1\%), classified as hydrocarbons, fused heterocyclic compounds, ester, and terpenes. The major constituents of dried leaves oil are (Chlorophenoxymethylenimino) sulphur pentafluoride $(74.46 \%)$ and 2,2,6,6-teteramethyl 3,5heptadione (17.27\%), while its minor constituents include Undecane (1.80\%), Squalene (1.62\%) and Tridecane (1.04\%), classified as heterocyclic compounds, ketone, hydrocarbon, ester, fatty acid, terpenes and alcohol. The following compounds; dicyclopentadiene, undecane, tridecane, hexadecane, dihydro dicyclopentadene and tetradecane are present in both essential oils. Essential oils are found to be a complex mixture of compounds which could be about twenty to sixty constituents [19]. Bambusa vulgaris has been reported to contain alkaloids, tannins, flavonoids and are useful as chemotherapies for microbial infections [20]. The leaf extracts of Bambusa vulgaris were reported to be a source of natural antioxidants and also of great pharmaceutical potentials [21,22]. The result obtained is similar to the report of Yue Jun et al., (2010) on essential oils from Bambusa vulgaris leaves from China in which 6,10,14-trimethyl-2pentadecanone - a ketone, 5,6,7,7a-tetrahydro4,4,7a-trimethyl-2 $(4 \mathrm{H})$ benzofuranone - heterocyclic compound and isophytol - terpene was present which were also identified in the fresh and dried leaf essential oils. However, in addition, these compounds: (Chlorophenoxymethylenimino) sulphur pentafluoride (74.46\%) and 2,2,6,6-teteramethyl 3,5heptadione $(17.27 \%$ ) are present in the Bambusa vulgaris leaves from Nigeria. The FT-IR of Bambusa vulgaris extracts have been reported to show the presence of aromatic compounds, aliphatic Halide compound (C-X), thiols, and amines [23] which also supported the presence of (Chlorophenoxymethylenimino) sulphur pentafluoride and 3-amino dibenzofuran found in the dried sample of the essential oil. The presence of esters in the oil suggests it could be used as antiinflammatory, antifungal and sedative agents. The oils could also be used as analgesic because of the presence of ketone in the oils.
Table I. Chemical composition of essential oils of Bambusa vulgaris leaf.

\begin{tabular}{|c|c|c|c|c|c|}
\hline No. & $\begin{array}{l}\text { Identified } \\
\text { Compoun } \\
\text { ds }\end{array}$ & $\mathbf{R I}$ & $\begin{array}{l}\text { \% } \\
\text { Comp } \\
\text { osition } \\
\text { on } \\
\text { Dried } \\
\text { Leaves }\end{array}$ & $\begin{array}{l}\% \\
\text { Comp } \\
\text { osition } \\
\text { on } \\
\text { Fresh } \\
\text { Leaves }\end{array}$ & $\begin{array}{l}\text { Molecular } \\
\text { Formula }\end{array}$ \\
\hline 1 & $\begin{array}{l}\text { Dicyclo } \\
\text { pentadien } \\
\text { e }\end{array}$ & 1018 & 0.08 & 0.72 & $\mathrm{C}_{10} \mathrm{H}_{12}$ \\
\hline 2 & $\begin{array}{l}\beta- \\
\text { Ocimene }\end{array}$ & 1026 & & 11.05 & $\mathrm{C}_{10} \mathrm{H}_{16}$ \\
\hline 3 & $\begin{array}{l}\text { Dihydro } \\
\text { dicyclopen } \\
\text { tadene }\end{array}$ & 1050 & 0.22 & & $\mathrm{C}_{10} \mathrm{H}_{14}$ \\
\hline 4 & Undecane & 1100 & 1.80 & 9.63 & $\mathrm{C}_{11} \mathrm{H}_{24}$ \\
\hline 5 & $\begin{array}{l}2,2,6,6- \\
\text { tetramethy } \\
\text { I } \quad 3,5- \\
\text { Heptadion } \\
\text { e }\end{array}$ & NA & 17.27 & & $\mathrm{C}_{11} \mathrm{H}_{20} \mathrm{O}_{2}$ \\
\hline 6 & Dodecane & 1200 & & 3.33 & $\mathrm{C}_{11} \mathrm{H}_{26}$ \\
\hline 7 & Tridecane & 1300 & 1.04 & 8.60 & $\mathrm{C}_{13} \mathrm{H}_{28}$ \\
\hline 8 & $\begin{array}{l}\text { Decanoyl } \\
\text { chloride }\end{array}$ & 1316 & & 4.75 & $\mathrm{C}_{15} \mathrm{H}_{19} \mathrm{ClO}$ \\
\hline 9 & $\begin{array}{l}\text { Tetradeca } \\
\text { ne }\end{array}$ & 1400 & 0.21 & & $\mathrm{C}_{14} \mathrm{H}_{30}$ \\
\hline 10 & $\begin{array}{l}\text { Allyl } \\
\text { decanoate }\end{array}$ & 1476 & & 0.51 & $\mathrm{C}_{13} \mathrm{H}_{24} \mathrm{O}_{2}$ \\
\hline 11 & Nerilidol & 1570 & & 3.10 & $\mathrm{C}_{15} \mathrm{H}_{26} \mathrm{O}$ \\
\hline 12 & $\begin{array}{l}\text { Hexadeca } \\
\text { ne }\end{array}$ & 1600 & 0.24 & 0.81 & $\mathrm{C}_{16} \mathrm{H}_{34}$ \\
\hline 13 & $\begin{array}{l}\text { Heptadec } \\
\text { ane }\end{array}$ & 1700 & 0.24 & & $\mathrm{C}_{17} \mathrm{H}_{36}$ \\
\hline 14 & $\begin{array}{l}\text { Octadeca } \\
\text { ne }\end{array}$ & 1800 & 0.20 & 0.79 & $\mathrm{C}_{18} \mathrm{H}_{38}$ \\
\hline 15 & Phytane & 1806 & & 1.24 & $\mathrm{C}_{20} \mathrm{H}_{42}$ \\
\hline 16 & $\begin{array}{l}\text { Vinyl } \\
\text { decanoate }\end{array}$ & 1812 & & 5.98 & $\mathrm{C}_{12} \mathrm{H}_{22} \mathrm{O}_{2}$ \\
\hline 17 & $\begin{array}{l}\text { Hexahydr } \\
\text { ofarnesyl } \\
\text { acetate }\end{array}$ & 1847 & 0.16 & & $\mathrm{C}_{18} \mathrm{H}_{36} \mathrm{O}$ \\
\hline 18 & Eicosane & 2000 & 0.20 & & $\mathrm{C}_{20} \mathrm{H}_{42}$ \\
\hline 19 & $\begin{array}{l}\text { Cis- } \\
\text { Vaccenic }\end{array}$ & 2116 & 0.30 & & $\mathrm{C}_{18} \mathrm{H}_{34} \mathrm{O}_{2}$ \\
\hline
\end{tabular}




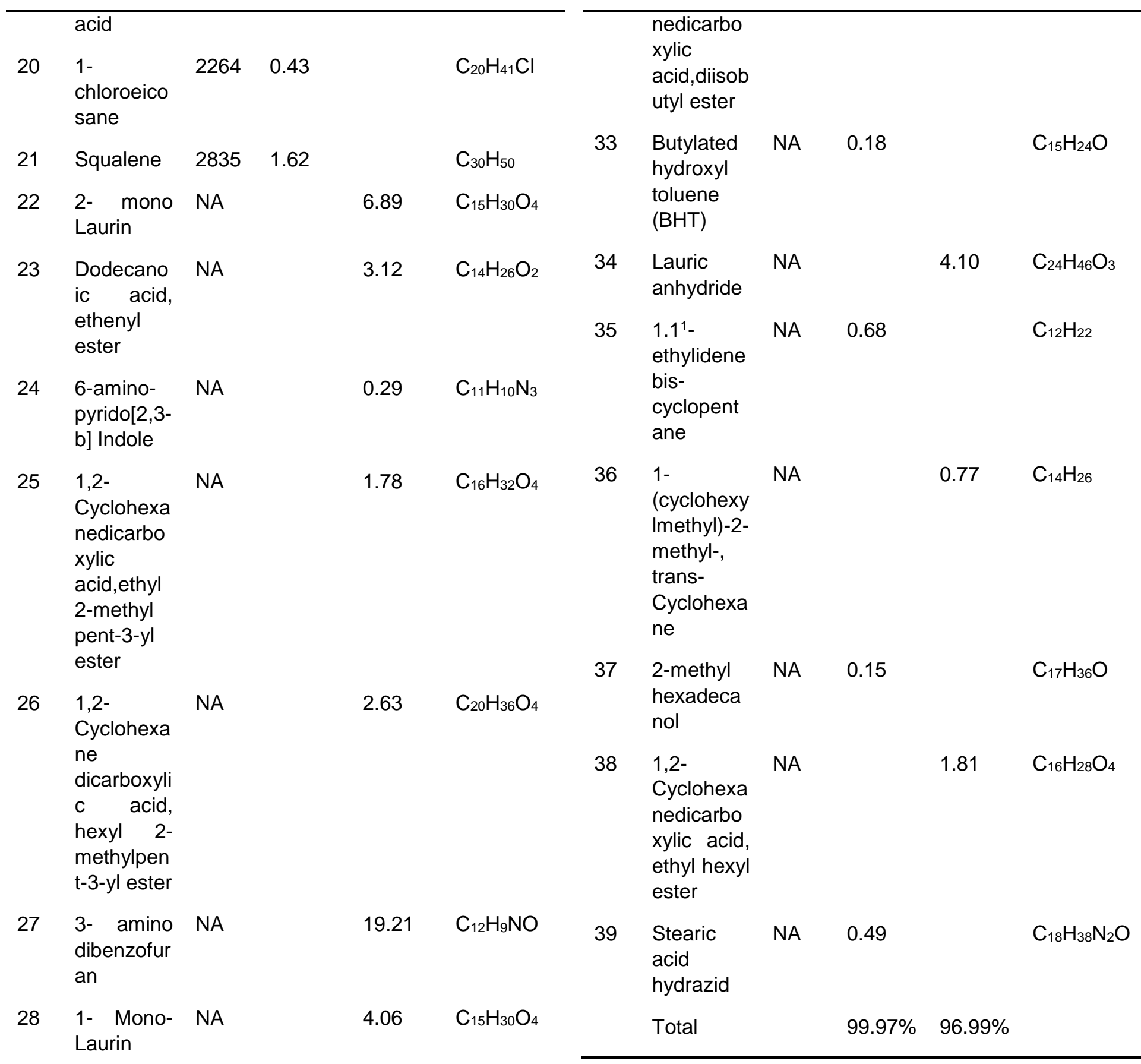

$\begin{array}{llll}\text { (Chloroph } & \mathrm{NA} & 74.46 & \mathrm{C}_{7} \mathrm{H}_{5} \mathrm{ClF}_{5} \\ \text { enoxymet } & & & \mathrm{NOS}\end{array}$

hylenimin

o)sulfur pentafluori de

$\mathrm{C}_{8} \mathrm{H}_{13} \mathrm{NO}_{2}$

b]pyridin-

6-on octahydro pyrano

Key: RI = Retention Index; NA = Literature Retention Index Not Available

\section{CONCLUSION}

The essential oil constituents of Bambusa vulgaris fresh and dried leaf samples were found to contain thirty-nine compounds. While some constituents of both oils are the same and similar to the constituents in literature, we report here the presence of some constituents that are detected in this plant from Nigeria but were absent in the one from China which may be due to their geographical and weather condition. The essential oil of this plant could be used as antiinflammatory, analgesic and antifungal due to the presence of ester, ketones, aldehydes and terpenes. However, biological activities such as anti- 
inflammatory, cytotoxicity and antimicrobial could be carried out in order to establish its efficacy.

\section{ACKNOWLEDGEMENTS}

We acknowledge the assistance of Dr. J.S Ashidi, Department of Plant Science, Olabisi Onabanjo University for the identification of the plant, Alese A. for the helping hand he rendered in the course of collection and extraction of the oil and Mr. Mejida of the University of Lagos, Nigeria where the GC and GC-MS analysis were done.

\section{COMPETING INTERESTS}

"Authors have declared that no competing interests exist."

\section{AUTHORS' CONTRIBUTIONS}

This work was carried out in collaboration among all Authors: ' Author OA' designed the study, performed the statistical analysis, wrote the protocol, and wrote the first draft of the manuscript. 'Author OO' and 'Author EA' managed the analyses of the study. 'Author $\mathrm{AH}$ and $\mathrm{AO}$ ' managed the literature searches. 'All authors read and approved the final manuscript.

\section{CONSENT}

Not Applicable

\section{ETHICAL APPROVAL}

Not Applicable

\section{REFERENCES}

[1] Goyal AK Brahma, BK. Antioxidant and nutraceutical potential of bamboo: an overview. J Fundam Appl Sci. 2014; 3: 2-10.

[2] Wang D Shen SJ. Bamboos of China. Timber Press, Portland, Oregon. 1987; 31-40

[3] Olayiwola OA. Phytochemicals and spectrophotometric determination of metal in various medicinal plants in Nigeria. Int J Eng Sci Inv. 2013; 2: 51-54.

[4] Tomalang FN, Lopez AR, Semara JA, Casin RF Espiloy ZB. Properties and utilization of Philippine erect bamboo. In Lessard, G., \& Chouinard, A. (Eds), International Seminar on Bamboo Research in Asia held in Singapore, 1980; 28-30: Proceedings Singapore: International Development 44 Research Center and the International Union of Forestry Research Organization. 1980; 266-275.

[5] Chew LT, Rahim S, Jamaludin K. Bambusa vulgaris for urea and cement-bonded particleboard manufacture. J Trop for Sci. 1992;4(3): 249-256.

[6] Choudhury D, Sahu JK, Sharma GD. Value addition to Bamboo Shoots: A review. J. Food Sci. Technol. 2012;49: 407-414.
[7] Nam JS, Chung HJ, Jang MK, Jung IA, Park S, Cho SI, Jung $\mathrm{MH}$. Sasa borealis extract exerts an antidiabetic effect via activation of the AMP-activated protein kinase. Nutr Res Pract. 2013;7(1): 15-21.

[8] Carey WM, Dasi JM, Rao NV, Gottumukkala KM. Anti-inflammatory activity of methanolic extract of Bambusa vulgaris leaves. Int. J. Green Pharm. 2009; 3(3): 234.

[9] Owokotomo IA, Owoeye G. Proximate analysis and antimicrobial activities of Bambusa vulgaris $L$. leaves' beverage. Afr. J. Agric. Res. 2011;6(21): 5030-5032.

[10] Zhang Y, Yao X, Bao B, Zhang Y. Anti-fatigue activity of a triterpenoid rich extract from Chinese bamboo shavings (Caulis bamfusaein taeniam). Phytother. Res. 2006;20(10):872-876.

[11] Senthilkumar MK, Sivakumar P, Changanakkattil F, Rajesh V, Perumal P. Evaluation of anti-diabetic activity of Bambusa vulgaris leaves in streptozotocin induced diabetic rats. Int. J. Pharm. Sci. Drug Res. $2011 ; 3(3)$ : 208-210.

[12] Zhong RZ, Zhou DW. Oxidative Stress and Role of Natural Plant Derived Antioxidants in Animal Reproduction. J Integr Agr. 2013; 12(10):1826-1838.

[13] Mahesh BM, Shashikant CD, Prasad GJ. Helminthiasis and medicinal plants: A review. Asian Pac J Trop Dis. 2015; 5(3): 175-180.

[14] Lodhi S, Jain A, Rai G, Yadav A. Preliminary investigation for wound healing and anti-inflammatory effects of Bambusa vulgaris leaves in rats. J Ayurveda Integr Med. 2016;7(1): 14-22.

[15] Tripathi Y. C., Jhumka Z. and Anjum N. Evaluation of total polyphenol and antioxidant activity of leaves of Bambusa nutans and Bambusa vulgaris. J Pharm Res. 2015; 9(4): 271-77.

[16] Libbey L. M. A paradox database for GC/ MS and other volatiles. J Essent Oil Res. 1991; 3:192-194.

[17] Adams RP. Identification of Essential Oils Compounds by Gas Chromatography and Mass Spectrometry. $4^{\text {th }}$ Edition Allured Publishing Corporation. Carol Stream, II, USA. 2009.

[18] YueJun H, YongDe Y, Feng T, XueFeng G, Jin W. Chemical compositions and antioxidant capacity of essential oils from different species of the bamboo leaves. Scientia Silvae Sinicae. 2010; 46(7) 120-128.

[19] Thormar H. Lipds and essential oils as antimicrobial agents. John Willey and Sons; Chichester 2011; 82.

[20] Owolabi MS, Lajide, L. Preliminary phytochemical screening and antimicrobial activity of crude extracts of Bambusa vulgaris Schrad. Ex J.C. Wendl. (Poaceae) from southwestern Nigeria. Am. J Essent. Oil. 2015; 3(1): 42-45.

[21] Ni Q, Xu G, Wang Z, Gao Q, Wang S, Zhang Y. Seasonal Variations of the Antioxidant Composition in Ground Bamboo Sasa argenteastriatus Leaves. Int. J. Mol. Sci. 2012; 13(2): 2249-2262.

[22] Wang J, Yue YD, Tang F, Sun J. TLC Screening for Antioxidant Activity of Extracts from Fifteen Bamboo Species and Identification of Antioxidant Flavone Glycosides from Leaves of Bambusa textilis Mc Clure. Mol. 2012;17(10): 12297-12311.

[23] Joselin J, Jenitha S, Brintha TSS, Jeeva S, Sukumaran S. Phytochemical and FT-IR Spectral 
Analysis of Certain Bamboo Species of South India. J

Biodivers Bioprospect Dev. 2014; 1(1): 1-9 